UDC 1:343.1UDC2:343.13

DOI https://doi.org/10.32849/2663-5313/2021.9.20

\author{
Mykola Ostrenko, \\ Adjunct at the Department of Criminal Procedure, National Academy of Internal Affairs, 1, Solomianska \\ square, Kyiv, Ukraine, postal code 03035, Mykola_Ostrenko@ukr.net \\ ORCID: orcid.org/0000-0002-7901-0946
}

Ostrenko, Mykola (2021). Definition of the term "rehabilitation" in criminal procedure law of Ukraine. Entrepreneurship, Economy and Law, 9, 136-141, doi: https://doi.org/10.32849/ 2663-5313/2021.9.20

\title{
DEFINITION OF THE TERM "REHABILITATION" IN CRIMINAL PROCEDURE LAW OF UKRAINE
}

Abstract. The aim of the study is to analyse some definitions of the term of rehabilitation of persons unlawfully prosecuted and, consequently, to synthesise the author's perspective on this term, which should correspond to modern legislative trends. Results. The relevance of the article is determined by the fact that the criminal procedure legislation and the derivative legal science of criminal procedure never stand still and always continue the search to legislate unregulated relations and improve existing legal regulations. To date, the concept of rehabilitation is not finally resolved. It must repeal unlawful procedural decisions of law enforcement agencies and fully restore previously lost and limited rights of a rehabilitee. The Ukrainian criminal procedure legislation in force and the science of criminal procedure are in a state of continuous change and search with regard to regulating current or legislating unregulated legal relations. Nowadays, the problem of regulating rehabilitation relations in criminal proceedings has become acute, first of all, there is no definition of the term "rehabilitation", which would provide a relevant and legal interpretation of the above phenomenon in criminal proceedings. The aim of the article is to analyse some definitions of the term of rehabilitation of persons unlawfully prosecuted and thus, synthesise the author's perspective on this term, which should correspond to modern legislative trends. The article analyses the authors' definitions by legal scholars: Bezliepkin B.T., Tadzhyiev T.T., Shylo N Ya., Skvortsov M.M., Boitsova L.V., Vitske R.E., Antonov V.I., Klimov H.Z., Rohachev S.O., Shumylo M Ye., Koval O., Mazur M.R., and Kaplina O.V. Conclusions. In the course of investigation, the author concludes that in most cases the definitions render the term "rehabilitation" in the "broad" meaning, and the author emphasizes that the term "rehabilitation" in criminal proceedings should be considered as a process inseparable from the criminal procedure and have features, namely: observance of the principle of publicity, compensation for pecuniary and non-pecuniary damage, and complete (comprehensive) restoration by public authority/authorities of the lost rights of a person unlawfully prosecuted (suspect, accused, convict). Finally, the author's definition of the term "rehabilitation" is given.

Key words: criminal procedure, institute of rehabilitation, cancellation of the decision, restoration of rights.

\section{Introduction}

The criminal procedure legislation and the derivative legal science of criminal procedure never stand still and always continue the search to legislate unregulated relations and improve existing legal regulations. To date, the concept of rehabilitation is not definitively resolved. It must repeal unlawful procedural decisions of law enforcement agencies and fully restore previously lost and limited rights of a rehabilitee.

To date, the law has not established a procedure for the rehabilitation of persons unlawfully prosecuted in criminal proceedings. Nevertheless, despite the presence of many scientific proposals on the definition of this term, there is no official term of "rehabilitation".
The issue of rehabilitation has been under focus of many well-known researchers: B.T. Bezliepkin, L.V. Boitsova, O.V. Kaplina, A.O. Orlova, M.I. Pastukhov, O.O. Podopryhora, M.S. Strohovych, T.T. Tadzhyiev, D.V. Tatianin, M.Ye. Shumylo, A.M. Smirnova, et al. However, a scientific analysis of the provisions on rehabilitation provided for in the CPC of Ukraine requires further analysis and the regulatory mechanism.

In the study by A.M. Smirnov, the focus is on the concept of recovery for damages caused to victims of justice and abuse of power (Smirnov, 2004, pp. 42-62).

In turn, G.O. Yashina emphasises a set of rehabilitation provisions of foreign countries and rehabilitation provisions of repressed peo- 
ples and victims of political repression (Yashina, 2015, pp. 56-104).

The aim of the study is to analyse some definitions of the term of rehabilitation of persons unlawfully prosecuted and thus, synthesise the author's perspective on this term, which should correspond to modern legislative trends.

2. Features of defining terms in the legislation of Ukraine

To date, Ukrainian domestic legislation does not provide a clear answer as to how and in what manner to observe the principle of criminal procedure declared in Art. 2 of the CPC of Ukraine, namely "... that every person who has committed a criminal offence shall be prosecuted to the extent of his or her guilt, no innocent person shall not be accused or convicted, no person shall not be subjected to ungrounded procedural compulsion..." (Criminal Procedure Code of Ukraine, 2012), which, in the author's opinion, should be implemented through the institution of rehabilitation in criminal proceedings. Therefore, regarding the term "rehabilitation," or according to some scholars "legal rehabilitation," nowadays no unanimous perspective exists. The following terms under study permits concluding that most of scientists understand the term "rehabilitation" in a broad sense. The author holds that the national legislation in force allows the term "rehabilitation" to be considered in a narrow context due to the nature of the latter, that is, "rehabilitation in criminal procedure."

Soviet lawyer B.T. Bezlepkin argues that rehabilitation "should be considered as the acquittal of the defendant or the termination of a criminal case in respect of a convicted person, an accused person, or a suspect due to the absence of an event or constituent elements of a crime, or due to the lack of the proof of the commission of a crime in respect of these persons" (Bezlepkin, 1975, p. 13). In our opinion, this term does not correspond to the complete picture of the phenomenon of "rehabilitation" since it does not provide for a procedure for recovery of lost rights to an individual.

Therefore, according to T.T. Tadzhiev, rehabilitation in criminal proceedings "is a decision of the competent law enforcement body, prescribed in a criminal procedure regulation, that states that the absence of event or the constituent elements of a crime or that participation in the commission of a crime of this person is not proven" (Tadzhyev, 1991, p. 15). T.T. Tadzhiev's perspective is consistent with that of B.T. Bezlepkin and does not include a component of the participation of State authorities in the full restoration of lost rights as a result of unlawful criminal prosecution.

N.Ya. Shylo argues that rehabilitation is "not only the termination of criminal proceedings or the acquittal by a court of persons illegally prosecuted, the legal grounds and the range of actors, but also the legal effects (for example, restoration of the reputation and honour of innocent people and compensation for material damage)" (Shilo, 1981, p. 16). On the basis of this definition, N.Ya. Shylo does not determine the leading role of state bodies in rehabilitation measures, since it is the latter that have sufficient competence to realize the full and final restoration of the lost rights of a person. The author's term implies a number of features, bypassing its specific essence. It should also be noted that the category of "termination of criminal prosecution" may include the termination of criminal proceeding which is carried out not only on rehabilitative grounds.

According to M.M. Skvortsov, "rehabilitation in the social sense of its content should entail complete and unquestionable restoration of the reputation of the unlaw fully accused, restoration of his/her former rights, recovery for material damages caused" (Skvortsov, 1970, p. 111). When the author argues that studies "rehabilitation" in criminal procedure relations, he recognizes that the above phenomenon cannot exist in isolation from the science of criminal procedure at the present stage of the development of legal science, therefore, it should imply solving the problem of the very criminal procedure. This is more narrow, concrete than solving abstract "social problems." "Incorrect accusation" also does not provide the participant of a rehabilitative relations with the possibility of final restoration of lost rights, since the term "incorrect accusation" can be interpreted simultaneously in several meanings: how incorrectly, improperly, erroneously an indictment against a particular person has been made; an erroneous indictment may be made on the basis of a mistake by an authorized person (intentional or unintentional), or insufficient evidence or evidence obtained by unlawful means. Therefore, on the other hand, the term "incorrect accusation" can be used as in respect of the person guilty, but guilty of committing another crime. In such a case the participation of such a person in rehabilitation activities is inappropriate, the act of rehabilitation will be of useless legal force, or in other case only measures of so-called "partial rehabilitation" are permitted for such a person that does not completely reveal the full essence of the term "rehabilitation."

L.V. Boitsova argues that rehabilitation is "the return of lost rights and benefits, elimination of legal restrictions related to unlawful conviction, prosecution, deprivation of liberty of innocent persons, as well as restoration of further legal capacity" (Boitsova, 1990, p. 8). Moreover, while L.V. Boitsova properly identifies a list 
of the activities and means by which a person should be reinstated in his or her lost rights, but no chief executive (addressee) of such activities is identified, which is directly the State represented by its bodies and officials. The author has not provided for an obligation on the part of the State to compensate rehabilitees for property damage caused.

R.E. Vitske defines the concept of "rehabilitation" as follows: "This is a procedure for restoring the rights and freedoms of a person unlawfully unjustly subjected to criminal prosecution and compensation for the harm caused to $\mathrm{him} / \mathrm{her}$, as well as restoration of reputation, honour of innocent citizens" (Vitske, 2007, p. 11). Vytske's definition quite aptly states that "rehabilitation" in criminal procedure is first and foremost a practice. But this definition is somewhat general, since the phrase "innocent citizens" enables ambiguous interpretations. Citizens may be innocent due to unlawful accusations and to criminal, disciplinary, administrative, civil and other charges.

According to V.I. Antonov, rehabilitation is "annulment of legal effects of repression, restoration of legal position and reputation of a person, as well as compensation for damages caused" (Antonov, 2001, p. 11). In this case, the author defines the concept of "rehabilitation" in a broad meaning. Nevertheless, as we have already stated, modern legal science cannot envisage rehabilitation separately from criminal proceedings, nor can the specific scope of legal relations and the actors involved in the implementation of rehabilitation be defined.

With regard to the definition of G.Z. Klimova, it can be concluded that the latter along with the previous two terms, proposed by scientists, also provides a definition of rehabilitation in the same broader context, "Rehabilitation is a legal means of correcting gross investigative and judicial errors. It occurs there and when the fact of unlawful prosecution is involved" (Klimova, 2005, p. 93).

S.O. Rogachev considers that "rehabilitation is a recognition by the State, through the person conducting the initial inquiry, the investigator or the court, of the unlawfulness of the criminal prosecution of a person by issuing a decision, determination of a sentence or a sentence and providing an opportunity for the rehabilitee to restore the violated rights and to recover all damages caused" (Rogachev, 2009, p. 154). Rehabilitation is an objective process carried out in accordance with the principles of criminal procedure. The role of the person conducting the initial inquiry, the investigator or the court is merely an instrument whose decision should be aimed at eliminating prior errors committed and establishing an offence by fal- sification, as a further obligatory ground for the opening of disciplinary/criminal proceedings on the facts revealed. Providing an opportunity for restoration does not constitute a de facto remedy. Rehabilitation was in fact a guarantee of ensuring that all perpetrators have brought to justice and that innocent persons have not been liable. Therefore, the possibility of ensuring the restoration of lost human rights should not be a substitute for the actual restoration of lost rights in the event of establishing the unlawfulness of the decisions.

3. State responsibility to a person in criminal proceedings

Domestic scientists in the field of criminal procedure advocate similar approach to thenatureand observance of the principleofpublicity. For example, according to M.Y. Shumylo, "Rehabilitation is a form of implementing the principle of State responsibility to the person in criminal proceedings. It is an institution of public law in which the law-restoring criminal procedure relations is regulated on the basis of formality, using under subsidiary terms provisions in civil, labour, pension and other branches of law, where the leading actor is the State in the person of the court" (Shumylo, 2019, p. 600). Therefore, in the author's view, the concept of responsibility to one person is erroneous, since the State is a systemically important collective actor that realizes its interests through the state authorities, as an instrument for the realization of socially important needs. Consequently, to oppose the State and one person is, according to the auhtor, somewhat inappropriate. Rehabilitation, as an integral part of criminal proceedings, is itself part of public law and therefore the principle of publicity may not be defined as leading in the process of rehabilitation.

According to O. Koval, "Rehabilitation in criminal proceedings is a system of social and legal measures provided for by law aimed at the full restoration of previous human rights that have been unlaw fully prosecuted or convicted, and compensation for damage caused» (Koval, 2012, p. 144). Thus, a person may be considered criminally liable if he or she acquires the status of a convicted person. In such a case, it would be advisable to mention either the "unlawfully prosecuted" or the "wrongfully convicted," since the contents of these wordings are identical.

O.V. Kaplina argues that "rehabilitation is a set of social and legal measures aimed at full restoration of the previous rights of a citizen unlawfully prosecuted or convicted, and compensation for damage caused" (Kaplina, 1998, p. 183). This term does not generally cover the process of rehabilitation, nor does the leading role of the State is considered, since the latter, 
through its legislation, requires the observance of the fundamental principles of criminal procedure and through its bodies, ensures them in the social and legal sphere. Furthermore, the latter does not provide the full set of measures to eliminate all suspicions and charges which is the priority of criminal procedure responsibility.

M.R. Mazur concludes that "the Ukrainian lawmaker considers rehabilitation as an acquittal for a person, the termination of a criminal case against him/her on rehabilitative grounds, and the subsequent restoration of his/her violated, restricted rights as an effect of rehabilitation. Therefore, a person is rehabilitated if in respect of him/her such acts are pronounced, issued (adopted) and who has the right to restoration of violated rights and legitimate interests and the right to compensation for damage caused" (Mazur, 2011, p. 174). This definition by M.R. Mazur does not indicate that a consistent list of these decisions cannot exist in isolation from the public sphere, especially from law enforcement officials, authorised in specific criminal proceedings and other officials of public authorities, whose activities in the rehabilitation process engage the restoration of lost rights on the basis of a rehabilitation decision. That is, the public authorities in general. Thus, having defined the list of decisions necessary for rehabilitation, the latter has missed the key relationship of the "humanState," which, in our opinion, should also be reflected in the definition.

Therefore, rehabilitation in criminal proceedings should have the following characteristics: observance of the principle of publicity, compensation for pecuniary and non-pecuniary damage, and complete (comprehensive) restoration by public authority/ authorities of the lost rights of a person, unlawfully prosecuted (suspect, accused, convicted). According to V.K. Voloshina, "The public nature of criminal procedure entails the existence of a system of controlling and supervisory powers designed to prevent possible arbitrariness on the part of the officials conducting the proceedings, to protect citizens from exposing to groundless accusations, condemning, from unlaw ful restriction of rights and freedoms" (Voloshyna, 2012), in other words, the principle of publicity in criminal proceedings is based on the exis- tence of a system of State bodies with powers of control and supervision, and characterized by the binding nature of the decisions taken to ensure the protection of the rights and freedoms of everyone party to criminal proceedings. The basis of civil liability of officials conducting criminal proceedings to persons aggrieved by such decisions, that is, the basis for compensation for pecuniary and non-pecuniary damage, prescribed in the provisions of art. 130 of the CPC of Ukraine. In the author's opinion, such basis derives from the principle set out above in art. 2 of the CPC of Ukraine. A complete (comprehensive) restoration of the lost rights by state authorities is regulated by art. 130 of the CPC of Ukraine, as well as by Law 266/94VR of Ukraine "On the procedure for compensation for damage caused to a citizen by unlawful actions of bodies of inquiry, pre-trial investigation, prosecutor's office and court" of January 01, 1994. Such measures provide for, on the basis of a court judgment on unlawfulness of the decisions, actions or omissions of bodies conducting investigative activities, bodies of pre-trial investigation, the Prosecutor's Office and the court, the return of illegally seized property and, in the event that it is not possible to make a return in kind, its cost is reimbursed from the enterprises, institutions and organizations to which it is donated (part 1 of art. 4), reinstatement in their labour (art. 6), residential (art. 9) and other rights (service, pension, other personal and property rights, etc.) (art. 15) (Law of Ukraine On the procedure for compensation for damage caused to a citizen by unlawful actions of bodies of inquiry, pre-trial investigation, prosecutor's office and court, 1994).

\section{Conclusions}

The above features allow the author to present his own understanding of the term of rehabilitation in criminal proceedings as follows: "Rehabilitation is a procedure defined by the Criminal Procedure Law, which provides, on the basis of publicity, for the full restoration of property and non-property rights to the person unlawfully prosecuted, as well as compensation for pecuniary and non-pecuniary damage on the grounds of a rehabilitation decision, which is binding on all State authorities and officials."

\section{References:}

Smirnov, A.M. (2004). Pravovoi status zhertv pravosudiia i zloupotrebleniia vlastiu kak osobii vid pravovogo statusa cheloveka [Legal status of victims of justice and abuse of power as a special type of legal status of the person]. Candidate's thesis. Kharkiv. (in Russian).

Yashina, G.O. (2015). Konstitutsionno-pravovye osnovy reabilitatsii v Rossiiskoi Federatsii [Constitutional and legal bases of rehabilitation in the Russian Federation]. Candidate's thesis. Penza. (in Russian). 
Kryminalnyi protsesualnyi kodeks Ukrainy : pryiniatyi 20 lyst. 2012 roku [Criminal Procedure Code of Ukraine from November 20 2012]. (2012). zakon.rada.gov.ua. Retrieved from https://zakon. rada.gov.ua/laws/show/4651-17\#n2503 (in Ukrainian).

Bezlepkin, B.T. (1975). Voprosy reabilitatsii na predvaritelnom sledstvii [Rehabilitation issues at the preliminary investigation]. Gorkii. (in Russian).

Tadzhyev, T.T. (1991). Problemy reabilitatsii v sovetskom ugolovnom protsesse [Problems of rehabilitation in the Soviet criminal process]. Extended abstract of Doctor's thesis. Tashkent. (in Russian).

Shilo, N.Ya. (1981). Problema reabilitatsii na predvaritelnom sledstvii [The problem of rehabilitation in the preliminary investigation]. Ashgabat. (in Russian).

Skvortsov, N.N. (1970). Pravovyie posledstviia opravdaniia [Legal consequences of justification]. Sovetskoe hosudarstvo y pravo - Soviet State and Law, 9. (in Russian).

Boitsova, L.V. (1990). Reabilitatsiia neobosnovanno osuzhdennykh grazhdan [Rehabilitation of unreasonably convicted citizens]. Extended abstract of candidate's thesis. Leningrad. (in Russian).

Vitske, R.E. (2007). Poniatiye reabilitatsii v ugolovnom protsesse Rossii [The concept of rehabilitation in the criminal process of Russia]. Rossiiskii sledovatel - Russian Investigator, 22. (in Russian).

Antonov, V.I. (2001). Institut reabilitatsii i iego ugolovno-pravovoye znacheniie [Institute of rehabilitation and its criminal law value]. Extended abstract of candidate's thesis. Izhevsk. (in Russian).

Klimova, G.Z. (2005). Reabilitatsiia kak pravovoi institut [Rehabilitation as a legal institution]. Sochi. (in Russian).

Rogachev, S.O. (2009) Reabilitatsiia v ugolovnom protsesse [Rehabilitation in Criminal Procedure]. Moscow. (in Russian).

Shumylo, M.E. (2019). Vybrani pratsi [Selected works]. Kharkiv: Pravo. (in Ukrainian).

Koval, O. (2012). Porivnialna kharakterystyka instytutiv vypravdannia ta reabilitatsii osoby [Comparative characteristics of the institutions of acquittal and rehabilitation of the person]. Pidpryiemnytstvo, ekonomika, pravo - Entrepreneurship, Economy, Law, 2. (in Ukrainian)

Kaplina, O.V. (1998). Problemy reabilitatsii v uholovnom protsesse Ukrainy [Problems of rehabilitation in the criminal process of Ukraine]. Kharkiv. (in Russian).

Mazur, M.R. (2011). Zakhyst prav ta zakonnykh interesiv reabilitovanykh u kryminalnomu protsesi [Protection of the rights and legitimate interests of those rehabilitated in criminal proceedings]. Lviv. (in Ukrainian)

Voloshyna, V.K. (2012). Vyznachennia pryntsypu publichnosti ta ioho zmist na dosudovykh stadiiakh [Defining the principle of publicity and its content at the pre-trial stages]. Aktualni problemy vlady ta prava - Actual Problems of Power and Law, 14. (in Ukrainian)

Zakon Ukrainy Pro poryadok vidshkoduvannya shkody, zavdanoi hromadyanynovi nezakonnymy diyamy orhaniv, shcho zdiysnyuyut operatyvno-rozshukovu diyalnist, orhaniv dosudovoho rozsliduvannya, prokuratury i sudu : pryiniatyi 1 sich. № 266/94-BP [Law of Ukraine On the procedure for compensation for damage caused to a citizen by unlawful actions of bodies of inquiry, pretrial investigation, prosecutor's office and court from January 011994 № 266/94-BP]. (1994). zakon. rada.gov.ua. Retrieved from: https://zakon.rada.gov.ua/laws/show/266/94-\%D0\%B2\%D1\%80\#Text (in Ukrainian)

\section{Микола Остренко,}

ад'юнкт кафедри кримінального прочесу, Нащіональна академія внутрішніх справ, площа Солом'янська, 1, Київ, Україна, індекс 03035, Mykola_Ostrenko@ukr.net

ORCID: orcid.org/0000-0002-7901-0946

\section{ВИЗНАЧЕННЯ ТЕРМІНУ «РЕАБІЛІАЦІЯ» У КРИМІНАЛЬНОМУ ПРОЦЕСУАЛЬНОМУ ПРАВІ УКРАЇНИ}

Анотація. Актуальність статті полягає в тому, що кримінальне процесуальне законодавство та похідна від нього правова наука кримінального процесу ніколи не стоять на місці, постійно й безперервно продовжують пошуки з унормування неврегульованих відносин і вдосконалення чинних нормативно-правових актів. На сьогодні не досить вирішені питання інституту реабілітації, який повинен не лише скасувати незаконно прийняті процесуальні рішення правоохоронних органів, а й повністю та остаточно повернути раніше втрачені й обмежені права реабілітанта. Метою статті є аналіз деяких визначень терміна «реабілітація осіб, незаконно притягнутих до кримінальної відповідальності» та подальший синтез авторського бачення цього поняття, яке має відповідати сучасним законодавчим тенденціям. Результати. Чинне українське кримінальне процесуальне 
законодавство та наука кримінального процесу перебувають у стані безперервних змін і пошуків з урегулювання чинних актів або унормування ще не врегульованих правовідносин. На сьогодні гостро постала проблема з урегулювання реабілітаційних правовідносин у кримінальному процесі. Зокрема, відсутнє визначення терміна «реабілітація», який надав би актуальне й легальне визначення вказаного явища у кримінальному процесі. У статті міститься аналіз авторських визначень таких науковців-правників: Б.Т. Безлєпкіна, Т.Т. Таджиєва, Н.Я. Шила, М.М. Скворцова, Л.В. Бойцової, Р.Е. Віцке, В.І. Антонова, Г.З. Климова, С.О. Рогачева, М.Є. Шумила, О.М. Коваль, М.Р. Мазур, О.В. Капліної. Висновки. У ході дослідження зроблено висновок, що в більшості випадків учені розуміють термін «реабілітація» в «широкому» його тлумаченні. Натомість автор наголошує на тому, що поняття «реабілітація» у кримінальному процесі варто розуміти як процедуру, що є невід’ємною від кримінального процесу. Ця процедура характеризується такими ознаками, як дотримання принципу публічності, відшкодування майнової та немайнової шкоди, усебічне (комплексне) поновлення органами/органом державної влади втрачених прав особи, незаконно притягнутої до відповідальності (підозрюваного, обвинуваченого, засудженого). Надано авторське визначення терміна «реабілітація».

Ключові слова: кримінальний процес, інститут реабілітації, скасування рішення, поновлення прав.

The article was submitted 15.09.2021

The article was revised 06.10.2021

The article was accepted 27.10.2021 